\title{
ПРОБЛЕМНІ ПИТАННЯ НАДІЙНОСТІ ПОРОШКОВИХ ЗАСОБІВ ПОЖЕЖОГАСІННЯ I ШЛЯХИ ЇХ ВИРІШЕННЯ
}

В. В. Кавецький, М. В. Білошицький, канд. хім. наук, С. А. Єременко, канд. техн. наук, А. В. Пруський, канд. техн. наук, М. І. Копильний, О. В. Корнієнко

ТОВ «Незалежна лабораторія пожежної безпеки»

Український науково-дослідний інститут цивільного захисту, Україна

Інститут державного управління у сфрері цивільного захисту, Україна

\section{ІНФОРМАЦІЯ ПРО СТАТТЮ}

Надійшла до редакції: 04.06.2019

Пройшла рецензування:25.06.2019

\section{КЛЮЧОВІ СЛОВА:}

вогнегасники, вогнегасні порошки, показники якості, стандарти,

випробування, розривний тиск, хімічний склад вогнегасних порошків.

\begin{abstract}
АНОТАЦІЯ
Проведено аналіз проблемних питань забезпечення надійності порошкових засобів пожежогасіння: забезпечення надійності якості вогнегасних порошків під час їхнього виготовлення, зберігання застосування, забезпечення якості, надійності використання, безпеки використання порошкових вогнегасників. Проаналізовано вплив на якість вогнегасних порошків хімічного складу, встановлено оптимальні концентрації компонентів вогнегасного складу, які забезпечують якість вогнегасних порошків. Проаналізовано вплив відміни обов'язкової державної реєстрації стандартів і ТУ, а також запровадження добровільності їх застосування на якість і надійність застосування порошкових засобів пожежогасіння. Запропоновано шляхи покращення якості вогнегасних порошків і порошкових вогнегасників і підвищення надійності гасіння ними пожеж.
\end{abstract}

До порошкових засобів пожежогасіння відносяться первинні засоби порошкового пожежогасіння (переносні порошкові вогнегасники повною масою до 20 кг), пересувні вогнегасники повною масою до 450 кг, автоматичні установки порошкового пожежогасіння, автомобілі порошкового пожежогасіння.

Вогнегасники порошкові переносні $\epsilon$ найбільш ефективними і найбільш поширеними первинними засобами гасіння пожежі на початковій стадії іiї виникнення, поки пожежа не набула великих розмірів i iï можна погасити співробітниками підприємств, установ, організацій до прибуття професійних пожежників. Від надійності роботи вогнегасника залежить життя співробітників, збереження матеріальних цінностей.

Вогнегасники переносні застосовуються для гасіння пожеж класів А (горіння твердих горючих речовин), В (горіння горючих рідин), С (горіння горючих газів). Порошок, яким споряджається такий вогнегасник, повинен бути багатоцільовим, тобто гасити пожежі класів А, B, С. Багатоцільові вогнегасні порошки виготовляються на основі (в основному) амонійних солей фосфорної кислоти, практично завжди 3 амофосу, мінерального добрива. Амонійні солі фосфорної кислоти інгібують проходження хімічної реакції горіння (припиняють полум'яне горіння), a також запобігають повторному займанню осередку пожежі класу А після інгібіювання полум'я за https//doi.org/10.33269/nvcz.2019.1.92-101 рахунок створення плівки розплаву, яка покриває жар мікронної товщини шаром i припиняє виділенню із нього газо- і пароподібних горючих продуктів термічного піролізу деревини, припиняючи утворення горючого середовища. Інші солі, інгібітори горіння, (хлориди натрію i калію, бікарбонати натрію і калію, сульфат калію, оксалат калію і багато інших) в умовах пожежі класу А не плавляться на поверхні жару і не утворюють захисної плівки, тобто не запобігають повторному займанню і не гасять пожежі класу А.

$\mathrm{y}$ роботі [1] наводиться детальний оглядовий аналіз результатів багатьох досліджень щодо впливу на якість вогнегасних порошків хімічного складу, вологи, насипної густини, дисперсності.

На надійність гасіння пожежі в першу чергу впливає наявність у вогнегасному порошку амонійних солей фосфорної кислоти інгібіторів полум'яного горіння. $€$ мінімальний вміст у вогнегасному порошку амонійних солей фосфорної кислоти, за якого відбувається інгібіювання полум'я, цей вміст залежить (в основному) від їх тонкості зламу (чим дрібніші частинки солей тим більша їх вогнегасна здатність, тобто для гасіння певного осередку пожежі необхідно менша кількість порошку). Мінімальний вміст також залежить і від наявності у порошку сульфату амонію, масової частки у порошку нерозчинних у воді дисперсних мінералів i багатьох інших факторів. Численними дослідженнями було 
встановлено, що мінімальний вміст у вогнегасному порошку амонійних солей фосфорної кислоти повинен бути не менше 22\% масових у перерахунку на $\mathrm{P}_{2} \mathrm{O}_{5}$.

Для гасіння пожеж класу А (горіння твердих речовин типу дерева) необхідно, щоб на поверхні матеріалу, що горить, утворилась тонка плівка розтопу солей порошку, яка б ізолювала горючу тверду поверхню від доступу кисню i перешкоджала виходу iз твердого матеріалу горючих газопароподібних продуктів термічного піролізу i утворення горючого середовища.

Дисперсні природні матеріали і гідрофобні речовини типу аеросилу перешкоджають утворенню плівки розтопу солей і зменшують вогнегасну здатність, а за певних концентрацій, приводять до припинення гасіння пожеж класу А. Полум'яне горіння припиняється, але із тліючого матеріалу через нещільну плівку розтопу продовжують виходити горючі газопароподібні продукти термічного розкладу і повторно утворюється горюче середовище, яке займається від високої температури розжарених твердих матеріалів.

Тому у вогнегасних АВС порошках вміст дисперсних водонерозчинних добавок підбирався i був таким, який забезпечував гасіння пожеж класу А. Великий вміст у багатоцільовому вогнегасному порошку тонкоподрібнених природних мінералів перешкоджає утворенню міцної ізолювальної плівки, така плівка не перешкоджає повторному займанню і такі порошки також практично не гасять пожежі класу А.

Під час розробки рецептури i технології виготовлення вогнегасних порошків проводяться дослідження щодо визначення оптимального хімічного складу (масової частки солей-інгібіторів, дисперсних i опудрюючих добавок, вологи, добавок для зменшення вартості,), який би задовольняв вимоги щодо забезпечення показників призначення, основним 3 яких є вогнегасна здатність.

Хімічний склад порошків регламентувався вимогами технічних умов, а показники призначення - вимогами стандартів і технічних умов (у технічних умовах було посилання на відповідні норми і методики стандартів).

Під час сертифікаційних випробувань спочатку визначали хімічний склад $\mathrm{i}$, у разі його відповідності вимогам ТУ проводили визначення показників призначення. Така процедура оцінки відповідності дозволяла контролювати якість порошків.
Технічні проблеми 3 якістю порошків 3'явилися в останні роки в основному тому, що виробники порошків намагаються виготовляти максимально дешеві порошки, досить часто за рахунок зниження вогнегасної здатності (зменшують вміст солей-інгібіторів), щоб можна було конкурувати на ринку. Вартість порошку зменшують за рахунок збільшення вмісту в ньому водонерозчинних природних дисперсних добавок, в т.ч. відходів виробництв, зменшення вмісту фосфатів амонію або i повною їх заміною, використанням солейінгібіторів (наприклад, хлориду натрію), які не гасять пожежі класу А.

Ці проблеми ще більше стали помітними після введення у дію Закону України «Про стандартизацію» (2014 рік) [2], яким відмінено обов'язкову державну реєстрацію стандартів і ТУ, а також запроваджено добровільність їх застосування. Недобросовісні виробники перестали наводити в ТУ дані щодо хімічного складу, наводять неважливі для характеристики якості порошку показники, за якими не можливо охарактеризувати якість порошку, бо вона залежить, в т.ч., від хімічного складу i, як наслідок цього, на сьогоднішній день практично неможливо встановити марку порошку (немає хімічного складу), а також встановити причини, чому порошок не забезпечує гасіння модельних осередків пожежі або реальних випадків загорянь. Це відкриває широкі можливості маніпулювання для недобросовісних виробників та постачальників вогнегасних порошків. Спочатку заявляється на випробування порошок, що має високу вартість, але добрі показники призначення, а в подальшому вартість зменшується за рахунок погіршання якості [1].

У квітні 2016 року на Південноукраїнську AEC був поставлений вогнегасний порошок «Омега АВС-50». Хімічний аналіз показав, що склад його не відповідає заявленому у ТУ [3]. Так, масова частка $\mathrm{P}_{2} \mathrm{O}_{5}$ складає 9,9\% (за ТУ не менше 22\%), нерозчинних речовин у соляній кислоті 65,2\% (за ТУ від $7 \%$ до 20\%). Нерозчинні в кислоті - це добавка-баласт, яка горіння не припиняє.

Виробництво неякісних порошків продовжується і на сьогодні. У 2018 році проводились випробування переносних вогнегасників. Вогнегасники не погасили модельні вогнища пожеж класів А $\mathrm{i}$ В. Проведеним хімічним аналізом встановлено, що у порошку відсутні фосфати, масова частка сульфату амонію складає 33,6\%, масова частка нерозчинних у соляній кислоті складає 24,8\%. 
Сума мас сульфату амонію $\mathrm{i}$ нерозчинних складає 58,4\%, тобто, у порошку є ще біля 40\% розчинної солі, більш всього це кухонна сіль. Порошок $з$ таким хімічним складом не може гасити пожежі класу А (немає фосфатів, які плавляться на поверхні жару i інгібують полум'яне горіння) і практично не може гасити пожежі класу В (мало кухонної солі, яка має низьку інгібіювальну здатність при гасінні полум'я).

Порошки високої якості продовжують вироблятися фірмами Європи і США. Хімічний склад вогнегасного порошку «ANSUL FORAY», відібраного в 2018 році із порошкового вогнегасника виробництва США: масова частка фосфатів у перерахунку на $\mathrm{P}_{2} \mathrm{O}_{5}$ складає $33,8 \%$, масова частка сульфату амонію - 21,7\%, масова частка речовин, нерозчинних у воді $-5,4 \%$. Такі порошки гарно гасять пожежі класів А і B.

Наявні проблеми 3 якістю вогнегасних порошків в Україні можливо буде вирішити 3 виконанням плану розроблення технічних регламентів на 2019 рік [4].

Пунктом 36 цього Плану передбачено розроблення i впровадження Технічного регламенту засобів цивільного захисту, який містить, у т.ч. вимогу впровадити в Україні стандарт EN 615:2009 [5]. У стандарті вказується, що у супровідній документації на вогнегасний порошок повинна бути надана інформація щодо масової частки усіх компонентів вогнегасного порошку із масовою часткою $\geq 10 \%$ і щоб сума мас усіх компонентів становила $\geq 90 \%$. У примітках до хімічного складу стандарту [5] регламентується допустиме максимальне відхилення від заявленого складу при аналізі, наводяться критерії сумісності порошку 3 піною, яка залежить від хімічного складу. Вказується, що не можна змішувати порошки, які призначені для гасіння пожеж класів А, В, С і класів В, C, тому що будуть взаємодіяти фосфат амонію $\left(\mathrm{NH}_{4} \mathrm{H}_{2} \mathrm{PO}_{4}\right)_{3}$ карбонатами $\left(\mathrm{NaHCO}_{3}, \mathrm{CaCO}_{3}\right)_{3}$ виділенням газу i збільшенням тиску у контейнерах (вогнегасниках) до значень розривання і можливого травмування людей. Вказується також, що порошок, який поглинув вологу, може грудкуватись і вивести 3 ладу вогнегасник під час гасіння.

Пунктом 37 плану [4] передбачено розроблення i впровадження Технічного регламенту аерозольних розпилювачів [6], яким впроваджуються в Україні вимоги Директиви Ради 75/324/СЕС від 20 травня 1975 року про наближення законодавства держав-членів стосовно аерозольних розпилювачів.
У Технічному регламенті аерозольних розпилювачів, як і в [5], є вимога щоб у супровідній документації на вогнегасний порошок надавалась інформація щодо вмісту усіх компонентів вогнегасного порошку iз масовою часткою $\geq 10 \%$ і щоб сума мас усіх компонентів становила $\geq 90 \%$ i регламентувалося допустиме максимальне відхилення від заявленого складу при аналізі.

Технічні регламенти будуть обов'язковими до виконання, у тому числі i виробниками вогнегасник порошків.

На нормативному рівні виробники вогнегасних порошків будуть зобов'язані виконувати вимоги $[5,6]$, тобто в Україні уже не буде випадків самовільного збільшення тиску у корпусах вогнегасників і їх розривання, тому що стандартом [5] заборонено у вогнегасних порошках класів А, В, С використовувати карбонати, що хімічно взаємодіють 3 фосфатами 3 виділення діоксиду вуглецю, що призводить до збільшення тиску.

Для забезпечення якості порошків необхідно вирішити ще й правове питання, а саме відновити дієві механізми контролю за якістю вогнегасних порошків та впливу на виробників та постачальників вогнегасних порошків, щоб не було поставок не якісного порошку, який не відповідає заявленому. Необхідно, щоб був вихідний контроль якості вогнегасного порошку на підприємстві виробнику, а також вхідний контроль у споживача, наприклад, на підприємстві виробнику вогнегасників.

Найбільш універсальними щодо можливості гасіння пожеж різних горючих речовин (горючих газів, горючих рідин, горючих твердих речовин) $\epsilon$ порошкові вогнегасники. Вимоги до якості вогнегасників наведені в [7-9]. Згідно [7, 8] вогнегасники перевіряють за показниками призначення (вогнегасна здатність вогнегасників під час гасіння пожеж класів А та В, довжина струменя вогнегасної речовини та мінімальна тривалість подавання вогнегасної речовини, оцінка теплохолодостійкості, стійкість до удару падаючим вантажем, стійкість до вібраційних навантажень, стійкість до дії внутрішньої корозії), а згідно з [9] перевіряється або тільки тип конструкції (експертиза технічної документації, погодження застосування відповідних матеріалів, перевіряється чи проведена атестація технології виконання нероз'ємних з'єднань), або якість продукції, у т.ч. тиск розриву корпусу й тиск спрацювання запобіжного клапану. 
На сьогоднішній день обов'язкової сертифікації виробів протипожежного призначення немає, є добровільна сертифікація й декларування. Виробник сам вибирає згідно з якими нормативними документами проводити оцінку відповідності і за якими показниками.

Тому на сьогодні видаються або сертифікати типу (відповідність технічному регламенту № 35) або реєструються органами сертифікації декларації відповідності виробника щодо відповідності вогнегасників вимогам регламенту за протоколами випробувань, що їх проводять призначені випробувальні лабораторії. Однак, ці випробувальні лабораторії можуть провести, у більшості випадків, тільки випробування корпусу випробувальним тиском, що явно не $\epsilon$ достатнім. Вогнегасник - це специфічний виріб, що може піддаватись дії механічних, кліматичних чинників, дії корозійноагресивного середовища тощо. Повний цикл випробувань може провести тільки випробувальна лабораторія, що має персонал відповідної кваліфікації, цілий ряд випробувального обладнання, в т.ч. i кліматичні камери. Як компромісний варіант, це можуть бути сумісні випробування різних випробувальних лабораторій.

Існує проблема щодо практичного застосуванням стандартів серії ДСТУ EN 3 [10], які введені у дію в Україні, але нормативного документу, що нормуе необхідність підтвердження відповідності вогнегасників вимогам цих стандартів 3 підтвердженням їх відповідності вимогам технічного регламенту [9] немає.

В 2018 році вийшли Правила експлуатації вогнегасників [11], в яких є також норми їх належності. Цей документ регламентує правила експлуатації вогнегасників відповідно до вимог ДСТУ, які на сьогоднішній день мають бути вже скасовані, але ніяк не регламентує застосування вогнегасників, виготовлених за вимогами стандартів серії ДСТУ EN-3. В теперішніх умовах, коли скасовані обов'язкова сертифікація та обов'язкове застосування стандартів, Правила експлуатації $\epsilon$ єдиним документом обов'язковим до виконання, яким регламентована обов'язкова відповідність вогнегасників певним стандартам, що i прописується у тендерних умовах, а підтвердженням відповідності може бути тільки наявність сертифіката відповідності. Тому враховуючи, що у [11] не йде мова про ДСТУ EN-3, ці стандарти і у подальшому не будуть впроваджуватись. Відсутність таких документів гальмує дійсне впровадження європейських стандартів, які юридично введені у дію, але фактично практичного застосування не знаходять, а заодно гальмується і дієвий контроль якості вогнегасників на стадії ї виготовлення.

Ще одна проблема, це відсутність дієвого контролю за продукцією, що вже випускається, за дотриманням умов експлуатації вогнегасників. Також умови закупівлі вогнегасників прописуються виходячи 3 меншої ціни, що призводить до закупівлі дешевих, але низької якості вогнегасників.

Виробники вогнегасників проходять сертифікацію 3 якісними, надійними більш дорогими комплектуючими, а потім виготовляють із дешевих, але не надійних комплектуючих, що знижує якість вогнегасників.

Низька якість вогнегасників обумовлюється як технічними причинами низької якості корпусу вогнегасника, так i причинами низької якості вогнегасного порошку, яким споряджається вогнегасник.

Прикладів того, що вогнегасники, які мають відповідні сертифікати відповідності, насправді виявляються низької якості та ще й небезпечними під час експлуатації, є досить багато. Так, 19.08.2013 на контрольних випробуваннях у м. Харків отримані негативні результати при випробуванні вогнегасників (таблиця 1, 2).

Таблиця 1 - Результати випробувань з визначення тиску розриву корпусів вогнегасника ВП-50.

\begin{tabular}{|c|c|c|}
\hline $\begin{array}{c}\text { № } \\
\text { вогнегасника }\end{array}$ & $\begin{array}{c}\text { Виміряна величина тиску розриву } \\
\text { корпуса, } \mathrm{P}_{\text {р.к. }} \text { МПа }\end{array}$ & $\begin{array}{c}\text { Критерій відповідності тиску розриву } \\
\text { корпуса: } \\
\mathrm{P}_{\text {р.к. }} \geq 7,0 \mathrm{MПа}\end{array}$ \\
\hline 1 & $\begin{array}{c}\text { 4,9. Розрив пройшов по основному } \\
\text { матеріалу по твірній }\end{array}$ & Не відповідає по тиску розриву \\
\hline 2 & $\begin{array}{c}4,0 . \text { Розрив пройшов по основному } \\
\text { матеріалу по твірній }\end{array}$ & Не відповідає по тиску розриву \\
\hline
\end{tabular}


Таблиця 2 - Результати випробувань 3 визначення тиску спрацювання запобіжного клапана на вогнегаснику ВП-50.

\begin{tabular}{|c|c|c|}
\hline $\begin{array}{c}\text { № } \\
\text { вогнегасника }\end{array}$ & $\begin{array}{c}\text { Виміряна величина тиску } \\
\text { Р р.к., МПа }\end{array}$ & $\begin{array}{c}\text { Критерій відповідності тиску } \\
\text { спрацювання згідно п. 4.4.11 } \\
\text { ДСТУ 3734-98 (ГОСТ 30612-99): } \\
\mathrm{P}_{\text {р.с. }}>1,6 \mathrm{MПа} \\
\mathrm{P}_{\text {р.к. }}<2,5 \mathrm{MПа} \\
\end{array}$ \\
\hline 1 & 2,60 & Не відповідає \\
\hline 2 & 2,55 & Не відповідає \\
\hline
\end{tabular}

Критерій відповідності тиску розриву корпусу пересувного вогнегасника становить $\geq 7,0$ МПа, а фактичне значення тиску розриву корпусу вогнегасника ВП-50(3) при проведенні контрольних випробувань у вересні 2013 року становило 4,0; 4,9 МПа, а вогнегасник ВП-100(3) розірвало при тиску 3,6 МПа та ще й по зварювальному шву, що не допускається. Якщо такий вогнегасник буде на випробовуванні у більшості призначених лабораторіях, які не знають i не враховують специфічні вимоги до вогнегасників, і випробування проводять тільки на стійкість до випробувального тиску, в цьому випадку це тиск 1,9 МПа. Корпус вогнегасника такий випробувальний тиск витримає, і виробник отримує сертифікат типу, але фактично в умовах експлуатації вогнегасник $є$ небезпечним. Мова вже не йде про те, що для забезпечення безпеки повинні перед гідравлічними випробуваннями проводитись ряд випробувань 3 механічної дії, корозійної стійкості та інше. Слід зауважити, що ці вогнегасники неодноразово розривались при експлуатації. Наприклад, у 2015 році розірвався вогнегасник ВП-50(3) на підприємстві ТОВ «Костал Україна», м. Переяслав-Хмельницький.

За результатами контрольних випробувань у м. Харків Державний центр сертифікації ДСНС України анулював сертифікат, але виробник поновив його через орган сертифікації у м. Харкові, не прийняв мір щодо вилучення 3 експлуатації бракованих виробів і вже в 2014 році стався вибух вогнегасника виготовленого в цей період.

На сьогоднішній день у торгову мережу потрапляють вогнегасники, які за технічними параметрами не відповідають вимогам ДСТУ 3675 і ДСТУ EN 3-8. Фото цих вогнегасників наведені на рисунках 1a, 16.

Але, якщо ще до 2013 року органи сертифікації відбирали вогнегасники для контрольних випробувань і таким чином був вплив на виробника після отримання ним сертифікату відповідності, то на сьогодні така робота не проводиться.

Як вже відмічалось, в теперішній час паралельно на вогнегасники діють як старі ДСТУ так і нові стандарти серії ДСТУ ЕN 3. І виробники вже користуються цим, але не для покращання якості та безпеки, а навпаки, для погіршення. Наприклад, для переносних вогнегасників п. 4.4.15 ДСТУ 3675-98 передбачає, що «Вогнегасник повинен бути стійким від самоперекидання (зберігати рівновагу), якщо він встановлений на горизонтальну поверхню і не закріплений. Конструкція корпусу вогнегасника повинна забезпечувати розміщення його дна на відстані не менше ніж 5 мм від горизонтальної поверхні». ДСТУ EN 3-8 допускає безпосередній контакт дна 3 поверхнею підлоги, але для запобігання негативних наслідків від ударів дна об підлогу, корозії дна в місці його контакту 3 поверхнею та інше, товщина дна повинна бути в 1,5 рази товще за розраховану товщину стінок інших частин вогнегасника. У результаті ми маємо, що у вогнегасниках, виготовлених у 2018 році за вимогами ДСТУ 3675 , дно контактує 3 поверхнею, але про збільшення товщини дна виробники забули. Тому за цим показником потрібно було б підтвердити його відповідність вимогам ДСТУЕN 3-8, а можливо і за усіма показниками безпеки.

На надійність роботи вогнегасників великий вплив має якість вогнегасного порошку. Від хімічного складу порошку залежить вогнегасна здатність вогнегасника, а від показників призначення порошку (дисперсності, насипної густини, питомої поверхні, текучості, термо- i вібростійкості, схильності до злежування) залежать показники роботи вогнегасника.

Якість вогнегасних порошків залежить від хімічного складу і регламентується відповідними нормативними документами - технічними умовами (ТУ), в яких раніше наводились вимоги щодо показників хімічного складу (масової частки компонентів), технологічних показників (дисперсність, питома поверхня, насипна густина) i показників призначення (вогнегасна здатність при гасінні пожеж класів А і В, гарантований термін зберігання у заводській упаковці, стійкості до вологопоглинання i комкування, текучість, термостійкість, вібростійкість). 


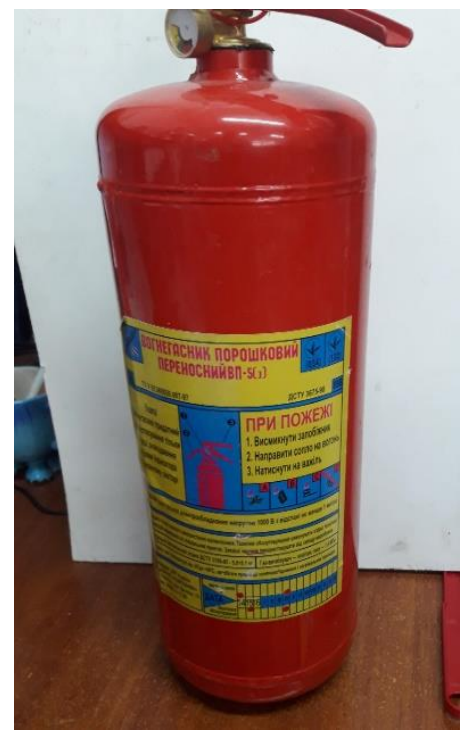

Рисунок 1а - Підроблений вогнегасник. Ознаки: Виконання корпусу не відповідає виробнику, відсутнє маркування методом клеймування корпусу вогнегасника

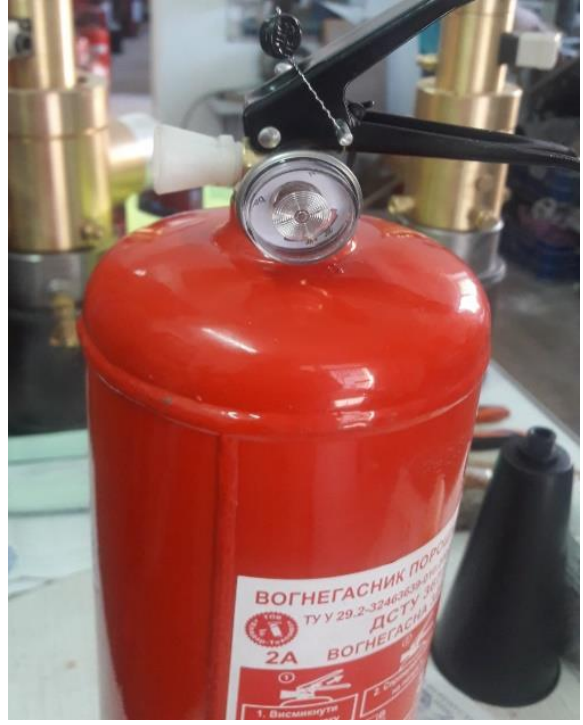

Рисунок 16 - Підроблений вогнегасник. Ознаки: Пломбування інше, інший запірно-пусковий пристрій, відсутній шланг, інший спосіб нанесення маркування на корпус

На рисунках 2a i 26 наведені результати випробувань на розривний тиск і показано, що вогнегасники розриваються по зварювальному шву, що не допускається.

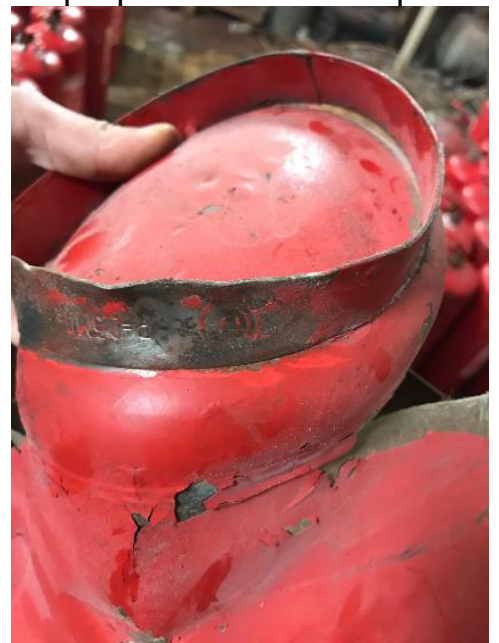

Рисунок 2a - Розривання підробленого корпусу вогнегасника. Зварювальні шви не відповідають вимогам НД (2018 рік)

На сьогоднішній день визначились три основні технічні проблеми 3 якістю багатоцільових (АBC) вогнегасних порошків в Україні:

1) зменшення вмісту фосфату амонію $\mathrm{i}$ практично повна заміна сульфату амонію в рецептурах вогнегасних $\mathrm{ABC}$ порошків на дисперсні водонерозчинні мінерали чи відходи виробництва;

2) заміна фосфату амонію на хлорид натрію (кухонну сіль);

3) використання у якості дисперсної водонерозчинної добавки карбонатвмісних мінералів, наприклад, доломітового борошна, яке складається із суміші карбонатів кальцію і магнію.

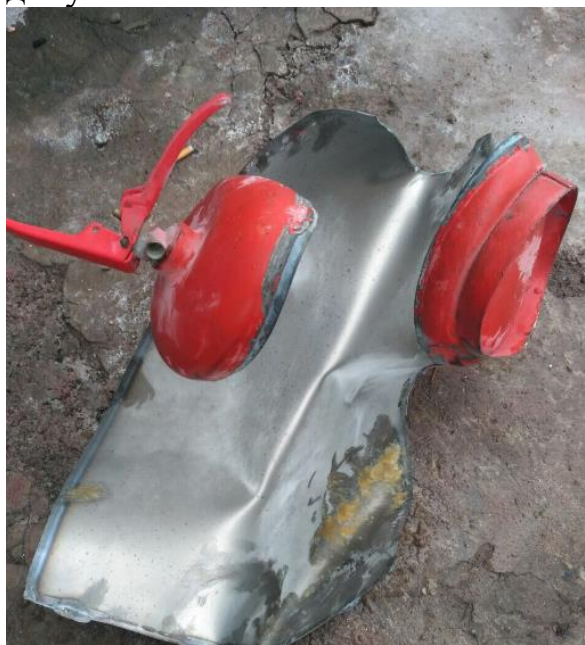

Рисунок $2 \mathrm{a}$ - Розривання підробленого корпуса вогнегасника. Зварювальні шви не відповідають вимогам НД (2018 рік)

Перші дві проблеми приводять до зменшення вогнегасної здатності при гасінні пожеж класів А i В (при зменшенні вмісту фосфату амонію) і до повної втрати вогнегасної здатності при гасінні пожеж класу А при заміні фосфатів амонію на хлорид натрію. Третя проблема приводить до збільшення тиску у вогнегаснику в результаті хімічної взаємодії карбонатів 3 фосфатом амонію $\left(\mathrm{NH}_{4} \mathrm{H}_{2} \mathrm{PO}_{4}\right)$. Наявність у рецептурі порошку карбонатів приводить, за наявності вологи, до хімічної взаємодії їх 3 фосфатом амонію 3 виділенням діоксиду вуглецю і підняттям тиску у вогнегаснику. Тиск піднімається до таких значень, що розриваються корпуси вогнегасників. Такі 
випадки були зафіксовані у різних користувачів вогнегасників.

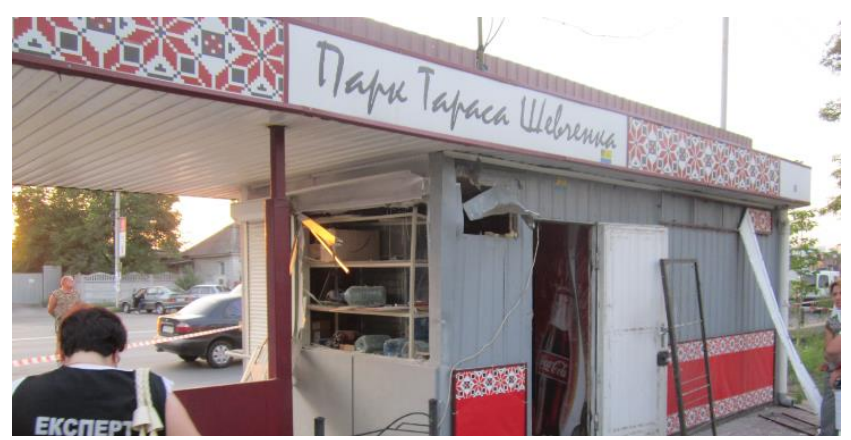

Рисунок $3 \mathrm{a}-$ Розривання порошкового вогнегасника, кафе «Парк Тараса Шевченка», м. Бровари (2015 рік)

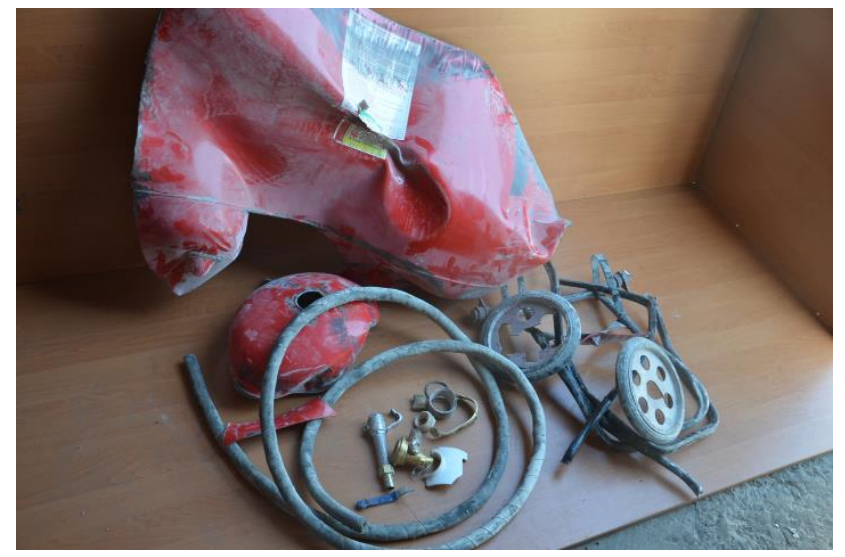

Рисунок $4 \mathrm{a}-$ Розривання вогнегасника ВП-50

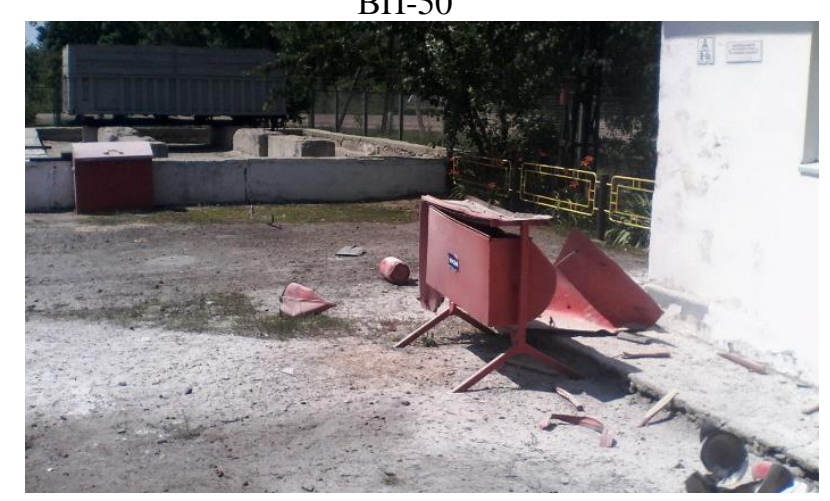

Рисунок 5a - Розривання вогнегасника у м. Миколаєві (2014 рік)

Ще одна проблема - це відсутність дієвого контролю за продукцією, що вже випускається, за дотриманням умов експлуатації вогнегасників. На рисунку 6 наведено стан вогнегасників, що надійшли на технічне обслуговування 3 маршрутного таксі у 2018 році. Виконання нижньої частини корпусу вказує на велику ймовірність можливого розриву. Корпус китайський, вимогам [9] не відповідає.

Наведені у статті результати досліджень щодо сучасного стану в Україні з якістю вогнегасних
На рисунках 3-5 наведено приклади розривання корпусів вогнегасників у результаті підвищення тиску.

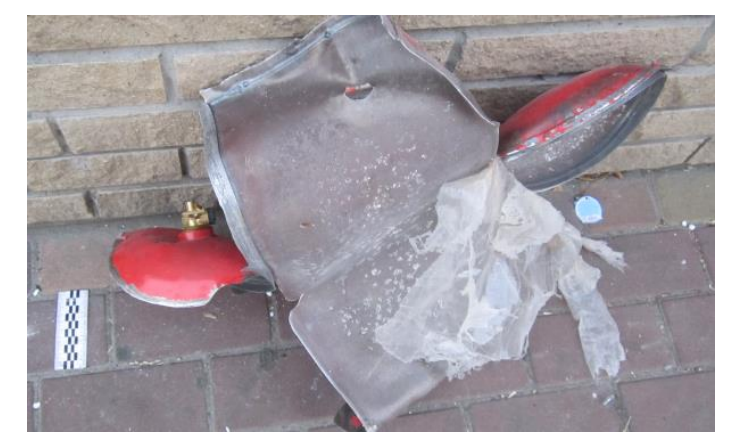

Рисунок 36 - Розривання порошкового вогнегасника, кафе «Парк Тараса Шевченка», м.

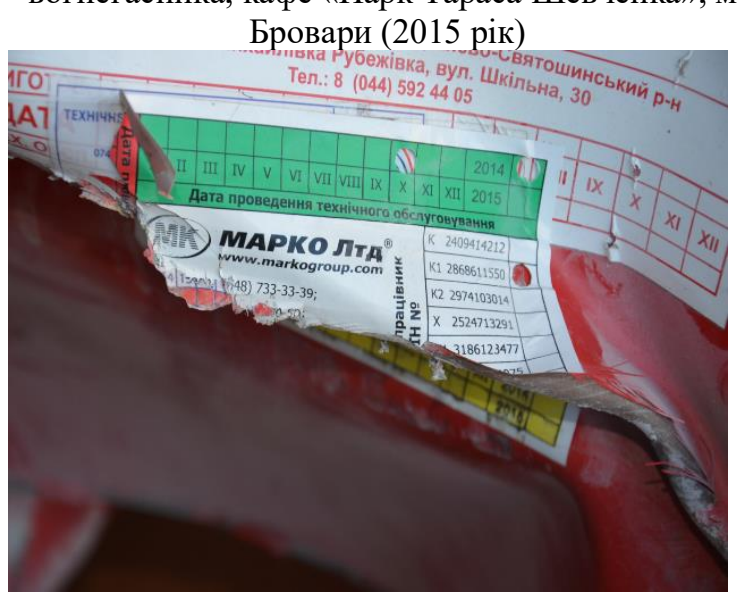

Рисунок 4б - Розривання вогнегасника ВП-50

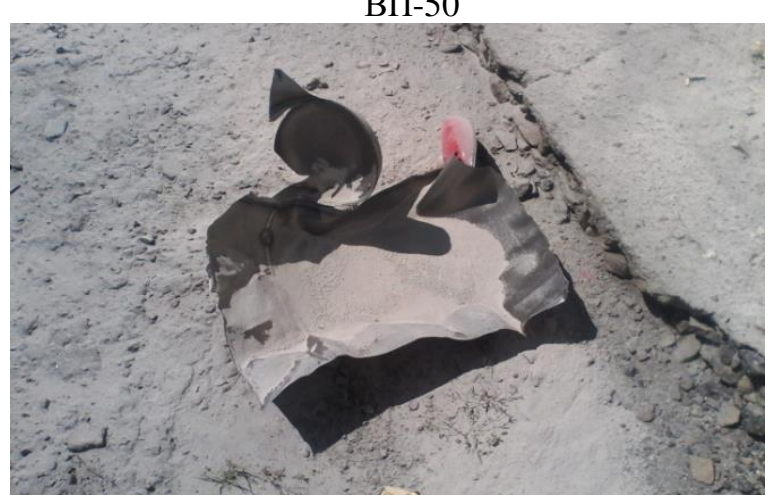

Рисунок 56 - Розривання вогнегасника у м. Миколаєві (2014 рік)

порошків і порошкових вогнегасників вказують на те, що на сьогодні в Україні відсутній дієвий контроль за якістю вогнегасних порошків i вогнегасників як на стадії виготовлення так і на стадії використання. На деякі марки вогнегасних порошків навіть не розробляються технічні умови iз зазначеним у них хімічним складом i показниками призначення, що сприяє фальсифікації таких порошків. 


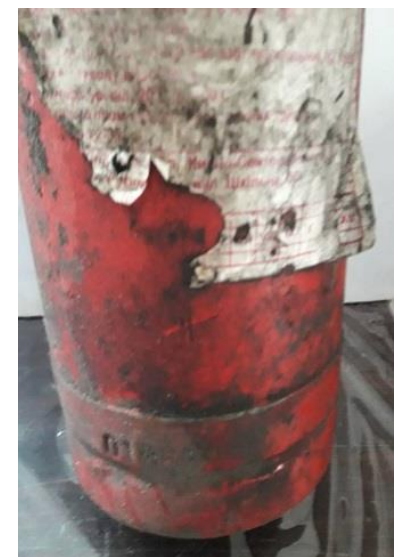

Рисунок 6а - Виконання нижньої частини корпусу вогнегасника не відповідає [9]

Значно погіршився стан 3 якістю порошків і вогнегасників 3 відміною обов'язкової державної реєстрації стандартів і ТУ на них, а також із запровадження добровільності їx застосування.

На сьогодні в Україні не існує цілісної послідовної системи як забезпечення, так i контролю якості вогнегасних порошків i порошкових вогнегасників під час їх виготовлення й використання.

Можливі шляхи вирішення проблемних питань:

1. Запровадження в Україні європейського стандарту EN 615 [5] і Технічного регламенту аерозольних розпилювачів [6].

2. Внесення змін та доповнень до Правил експлуатації та типові норми належності вогнегасників [11] з урахуванням усіх змін, що

\section{СПИСОК ЛІТЕРАТУРИ}

1. Білошицький М. В., Кавецький В. В., Копильний М. І. Проблеми 3 якістю вогнегасних порошків в Україні. Збірник наукових праць ІДУЦЗ, № 3, 2015, С.17-30

2. Закон України «Про стандартизацію» (Відомості Верховної Ради (ВВР), 2014, № 31, ст.1058) \{Із змінами, внесеними згідно із Законом № 124-VIII від 15.01.2015, ВВР, 2015, № 14, ст.96\}.

3. Порошки вогнегасні «Омега» ТУ У 20.5-367270061001:2013.

4. План розроблення технічних регламентів на 2019 рік. Затверджений наказом Міністерства економічного розвитку і торгівлі України від 05.03.2019 № 347.

5. EN 615-2009 Протипожежний захист. Вогнегасні речовини. Специфікація на порошки. Вимоги до вогнегасних порошків (крім порошків для гасіння пожеж класу D).

6. Технічний регламент аерозольних розпилювачів (проект).

\section{REFERENCES}

1. Biloshytskyi M. V., Kavetskyi V. V., Kopylnyi M. I. (2015) Problemy z yakistiu vohnehasnykh poroshkiv v Ukraini [Problems with the quality of fire-extinguishing powders in Ukraine]. Zbirnyk naukovykh prats IDUTsZ vol 3,.pp.17-30

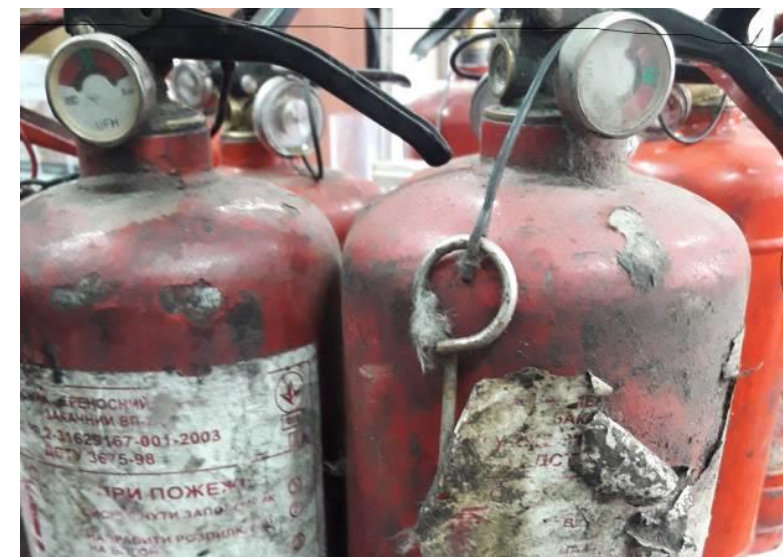

Рисунок $6 б$ - Стан вогнегасників, що надійшли на технічне обслуговування 3 маршрутного таксі

відбулися в нормативній базі $[5,10]$. Це стане правовим підгрунтям для впровадження в Україні стандартів $[5,10]$.

3. Запровадження механізму контролю за вогнегасниками, що надходять в експлуатацію щодо їх повної відповідності нормативному документу, за яким вони виготовлені.

4. Запровадження контролю якості (хімічного складу) вогнегасних порошків на підприємствах-виробниках технічних засобів порошкового пожежогасіння.

5. Опрацювання питання 3 Мінекономрозвитку щодо можливості видання розпорядження, яким би підтвердження відповідності вогнегасника технічному регламенту [14] (його безпека) могло б бути підтвердженням виробником його відповідності певній частині стандартів з серії ДСТУ EN-3

7. ДСТУ 3675-98 Пожежна техніка. Вогнегасники переносні. Загальні технічні вимоги та методи випробувань.

8. ДСТУ 3734-98 Пожежна техніка. Вогнегасники пересувні. Загальні технічні вимоги.

9. Технічний регламент безпеки обладнання, що працює під тиском, затверджений постановою Кабінету Міністрів України від 19.01.2011 № 35 (ТР № 35).

10. ДСТУ EN 3-8:2015 Вогнегасники переносні. Частина 8. Додаткові вимоги до EN 3-7 стосовно конструкції, опору тиску та механічних випробувань вогнегасників iз максимально допустимим тиском, що нижче або дорівнює 30 бар.

11. Правила експлуатації та типові норми належності вогнегасників, затверджені наказом МВС України від 15.01.2018 № 25 .

2. Zakon Ukrainy «Pro standartyzatsiiu» (Vidomosti Verkhovnoi Rady (VVR), 2014, № 31, st.1058) \{Iz zminamy, vnesenymy zghidno iz Zakonom № 124-VIII vid 15.01.2015, VVR, 2015, № 14, st.96\}. 
3. Poroshky vohnehasni «Omeha» TU U 20.5-367270061001:2013.

4. Plan rozroblennia tekhnichnykh rehlamentiv na 2019 rik. Zatverdzhenyi nakazom Ministerstva ekonomichnoho rozvytku i torhivli Ukrainy vid 05.03.2019 № 347.

5. EN 615-2009 Fire protection. Fire extinguishing media. Specifications for powders (other than class D powders).

6. Tekhnichnyi rehlament aerozolnykh rozpyliuvachiv (proekt).

7. DSTU 3675-98 Pozhezhna tekhnika. Vohnehasnyky perenosni. Zahalni tekhnichni vymohy ta metody vyprobuvan.

8. DSTU 3734-98 Pozhezhna tekhnika. Vohnehasnyky peresuvni. Zahalni tekhnichni vymohy.

9. Tekhnichnyi rehlament bezpeky obladnannia, shcho pratsiuie pid tyskom, zatverdzhenyi postanovoiu Kabinetu Ministriv Ukrainy vid 19.01.2011 № 35 (TR № 35)
10. ДСТУ ЕN 3-8:2015 Portable fire extinguishers - Part 8: Additional requirements to EN 3-7 for the construction, resistance to pressure and mechanical tests for extinguishers with a maximum allowable pressure equal to or lower than 30 bar.

11. Pravyla ekspluatatsii ta typovi normy nalezhnosti vohnehasnykiv, zatverdzheni nakazom MVS Ukrainy vid 15.01.2018 № 25 . 


\section{PROBLEMATIC ISSUES OF THE POWDER FIRE EXTINGUISHING MEANS RELIABILITY AND WAYS OF THEIR SOLUTION}

V. Kavetskyi, M. Biloshytskyi, Cand. of Sc. (Chem.), S. Yeremenko, Cand.of Sc., A. Pruskyi, Cand.of Sc. (Eng.), M. Kopylnyi, O. Korniienko

TOV «Nezalezhna laboratoriia pozhezhnoyi bezpeky», Ukraine

The Ukrainian Civil Protection Research Institute, Ukraine

Institute of Public Administration in the Sphere of Civil Protection, Ukraine

\section{KEYWORDS}

fire extinguishers, fire extinguishing powders, quality indicators, standards, testing procedure, burst pressure chemical composition of fire extinguishing powders.

\begin{abstract}
ANNOTATION
Problematic issues analysis concerning powder fire extinguishing means reliability was carried out, they are: ensuring the quality reliability of fireextinguishing powders during their production, storage and application; quality assurance; powder fire extinguishers' reliability and safety. It is emphasized that the technical problems related to quality of fireextinguishing powders having been raised in the last years are mainly due to the fact that the manufacturers of fire-extinguishing powders endeavour to produce the ones having the lowest prime cost, and this rather often takes place on account of lowering fire-fighting ability (they decrease content of inhibiting salts) in order to compete more effectively on the market. Prime cost of fire-extinguishing powder is lowered due to increasing content of water insoluble natural dispersed additives in it including industrial waste, diminishment of ammonium phosphates content or otherwise by complete substitution of the latter, and use of inhibiting salts (for instance, sodium chloride) unable to put out class A fires. Influence of chemical composition on the quality of extinguishing powders is analyzed. Optimal components of the fire extinguishing composition have been established which ensure quality of extinguishing powders. Effect of the Law of Ukraine "On Standardization" which abolished the mandatory state registration of standards and technical specifications as well as their voluntary application on the quality and reliability of powder fire extinguishing means has been studied. Problem issues are emphasized as well related to simultaneous validity in Ukraine both exceptionally national standards for portable and mobile fire extinguishers and national standards harmonized to appropriate European ones. Possible ways of quality improvement of fire extinguishing powders and powder fire extinguishers as well as fire extinguishing reliability enhancement have been proposed, in particular, through the introduction of EN 615 European standard and Technical regulations for aerosol dispensers in Ukraine, amending Regulations for use and typical rules of availability of fire extinguishers as well as introduction of mechanism of monitoring of fire extinguishers coming to use etc.
\end{abstract}

\section{ПРОБЛЕМНЫЕ ВОПРОСЫ НАДЕЖНОСТИ ПОРОШКОВЫХ СРЕДСТВ ПОЖАРОТУШЕНИЯ И ПУТИ ИХ РЕШЕНИЯ}

В. В. Кавецкий, М. В. Белошицкий, канд. хим. наук, С. А. Еременко, канд. техн. наук, А. В. Пруский, канд. техн. наук, Н. И. Копыльный, А. В. Корниенко

ООО «Независимая лаборатория пожарной безопасности», Украина

Украинский научно-исследовательский институт гражданской защиты, Украина

Институт государственного управления в сфрере гражданской защиты, Украина

\section{КЛЮЧЕВЫЕ СЛОВА}

огнетушители, огнетушащие

порошки, показатели качества, стандарты, испытания, разрывное давление, химический состав огнетушащих порошков.

\begin{abstract}
АННОТАЦИЯ
Проведен анализ проблемных вопросов обеспечения надежности порошковых средств пожаротушения, обеспечения надежности качества огнетушащих порошков во время их изготовления, хранения и использования, обеспечения качества, надежности использования порошковых огнетушителей. Проанализировано влияние на качество огнетушащих порошков химического состава, определены оптимальные концентрации компонентов огнетушащего состава, которые обеспечивают качество огнетушащих порошков. Проанализировано влияние введения в действие Закона Украины «О стандартизации» (2014 год), которым отменена обязательная государственная регистрация стандартов и ТУ, а также внедрена добровольность их использования, на качество и надежность применения порошковых средств пожаротушения. Предложены пути улучшения качества огнетушащих порошков и порошковых огнетушителей и повышения надежности тушения ими пожаров.
\end{abstract}

